\title{
Mapping geohistorical narratives: The Grand Duchy of Lithuania borderlands infrastructures project, $18^{\text {th }}$ century
}

\author{
Alberto Giordano $^{\mathrm{a}^{*}}$, Jurgita Verbickienè ${ }^{\mathrm{b}}$, Martynas Jakulis ${ }^{\mathrm{c}}$, Andrej Ryčkov ${ }^{\mathrm{d}}$, Aivaras Poška ${ }^{\mathrm{e}}$, Tim \\ Cole $^{\mathrm{f}}$
}

a Department of Geography, Texas State University, USA,ag22@txstate.edu

${ }^{b}$ Faculty of History, Vilnius University, Lithuania, jurgverb@gmail.com

${ }^{c}$ Faculty of History,Vilnius University,Lithuania,martynas.jakulis@gmail.com

${ }^{d}$ Faculty of History, Vilnius University,Lithuania, andrej.ryckov@gmail.com

e Faculty of History, Vilnius University, Lithuania, aivarasposka92@gmail.com

${ }^{f}$ Department of History, University of Bristol, UK, tim.cole@bristol.ac.uk

* Corresponding author

Keywords: HGIS, spatial humanities, $18^{\text {th }}$ century maps, Grand Duchy of Lithuania, borderlands.

\begin{abstract}
:
In this presentation, we discuss historical geographical research we are undertaking as an international team of historians, geographers, and GIScientists from Lithuania, the United Kingdom, and the United States. The project is sponsored by a three-year grant from the Lithuanian Research Council. Our region and historical period of interest are the borderlands between the Grand Duchy of Lithuania (GDL) and Prussia, on the GDL side, in the late $18^{\text {th }}$ century. These borderlands were crucial to the economy of the GDL in terms of international trade and the movement of people, as well as for national security.
\end{abstract}

The overall objectives of our project are to: a) analyse the spaces and places of the borderlands of the GDL; b) create a model for mapping and analysing geohistorical narratives that could be implemented in other historical contexts and other countries; c) create a multi-scale and multi-temporal portrait of the borderlands of the GDL at an unprecedented level of spatial detail. The main source for the project is the detailed description of the infrastructures of the GDL compiled in 1775 and later supplemented multiple times in preparation for economic reforms that were never undertaken due to the collapse of the Poland-Lithuanian Commonwealth at the end of the $18^{\text {th }}$ century. Preserved in the collection of the GDL's Treasury Commission of the Lithuanian State Historical Archives, the manuscripts contain descriptions of a vast number of infrastructural objects of different kind, including roads, bridges, canals, ferries, inns, border check points, and customs. The manuscripts also include a rich and at times very personal narrative and commentary of the structure of the GDL society at the time, including the actions of merchants and noblemen, clergy and commoners, smugglers and servants, and of the vast Jewish population living in the borderlands. The manuscripts describe in great detail the places of the GDL, including type of settlements, marketplaces, natural features, and communication networks. These extraordinary and understudied sources, which taken together amount to approximately 1000 pages, allow the researcher not only to study the historical geography of the GDL borderlands towards the end of the $18^{\text {th }}$ century, but also to reconstruct its social networks and the relationships between social classes and religious and ethnical groups. The sources are the centerpiece of a vaster collection of historical materials relative to the GDL in the late $18^{\text {th }}$ century that include maps, inventories, customs books, and other documents created at the same time and for similar reasons - to implement economic and political reforms - including the census of Jews of 1764, the general population census of 1790, the censuses of households conducted in the second part of $18^{\text {th }}$ century, as well as poll and other tax registers, travel diaries, correspondence, legal documents, tax accounts, and memoirs.

Our project is situated at the convergence of the digital humanities, the geospatial humanities, GIScience, and sociocultural and socio-economical historical studies. This is because, in addition to being mapped to create a HGIS of the GDL borderlands, the manuscripts in the collection of the GDL's Treasury Commission can be studied and analysed as literature as well as sociological treatises. The high spatial resolution, large geographical scale, and richness of the narrative lend themselves to the application of the analytical tools of spatial anaysis, text analysis, and social network analysis. From a methodological perspective, we are exploring using a variety of analitical tools that include spatial analysis and geovisualization for the quantitative GIS component, as well as QSR for mapping qualitative spatial relations. In addition to these GIS\&T methods and tools, we are using corpus linguistics (CL) and natural language processing (NLP), a set of computational methods for analyzing large bodies of text across corpora, to conduct a distant reading of the manuscripts.

In the course of our presentation, we will: a) describe the content of the manuscript and its historical context; b) share with the audience the data dictionary we created to systematically explore the manuscript; c) present a conceptual model that integrates geography and social networks towards an understanding of the economic and social conditions of the 
GDL borderlands at the end of $18^{\text {th }}$ centudy; d) share selected preliminary results centered around an analysis of the interactions and infrastructure networks of the borderlands. Emphasis will be placed on the most cartographic aspects of our work, most specifically the use of multiple sources as a basis for creating the HGIS. 